\title{
Are Changes in Species Composition on Central North Dakota Rangelands Due to Non-Use Management?
}

\section{By Shawn DeKeyser, Gary Clambey, Kelly Krabbenhoft, and Joel Ostendorf}

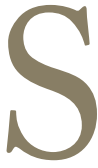

everal federally owned rangelands, such as waterfowl production areas, national wildlife refuges, and national historic sites in North Dakota, are being managed as non-use (idle or rest) areas based on the belief that livestock grazing is detrimental to historic anthropologic sites, wildlife, and native grassland health. It has become evident in more recent years that such management favors some invasive species such as smooth brome (Bromus inermis) or Kentucky bluegrass (Poa pratensis). ${ }^{1}$

One example of a site historically managed with non-use is the Knife River Indian Villages National Historic Site (KNRI; Fig. 1). The historic site is located near the confluence of the Knife and Missouri rivers in central North Dakota, and is of historic significance due to the numerous anthropologic sites left behind by the native Mandan and Hidatsa tribes living in the area before European settlement. Their villages were located on the historic site (Fig. 2), and the area was grazed by their horses and native herbivores. The villages were abandoned in 1845 following smallpox outbreaks and Dakota Indian raids. Euro-American settlement began 30-40 years later, and the historic site was then managed as a mixture of cropland and rangeland pastures for domestic cattle.

A vegetative inventory of existing rangeland, pasture, and woodland areas was completed in $1984^{2}$ subsequent to the National Parks Service's purchase of the land in 1974. Prior to 1974, all rangelands on the site were grazed by cattle, and after 1974, no grazing was allowed. Following this extended period of non-use (1974-2007), several of the rangeland ecological sites appear to have been dominated by smooth brome and Kentucky bluegrass. ${ }^{3}$ We were curious how much the ecological sites had changed in species composition. To answer the question, we surveyed the same ecological site transects utilizing the same sampling techniques used in
$1984,{ }^{2}$ and a comparison was made of relative cover in 1984 and 2007.

\section{Historic Vegetation of the Area}

The KNRI is found within the Northwestern Great Plains on the edge of the Missouri Plateau and River Breaks level IV ecoregions. ${ }^{4}$ The Missouri Plateau native prairies have deep Mollisol soils with a physiography divided between level to rolling plains. The native prairie tracts of KNRI consist of approximately 365 ha of varying ecological sites depending on landscape position and soil texture.

The vegetation is characteristically cool-season $\left(\mathrm{C}_{3}\right)$ dominated, northern mixed-grass prairie and has been classified as a wheatgrass-needlegrass (Elymus-Hesperostipa) type. ${ }^{5}$ Species in this vegetation type include western wheatgrass (Elymus smithii), green needlegrass (Nassella viridula), and blue grama (Bouteloua gracilis) dominating loamy ecological sites. ${ }^{6}$ Big bluestem (Andropon gerardii), switchgrass (Panicum virgatum), and Indiangrass (Sorghastrum nutans) dominate loamy overflow sites (swales). ${ }^{7}$ Sand bluestem (Andropogon ballii), little bluestem (Schizachyrium scoparium), and prairie sandreed (Calamovilfa longifolia) dominate the stream terrace alluvial sands ecological sites. ${ }^{8}$ Prairie sandreed and little bluestem are the dominants on the higher and drier sandy ecological sites. ${ }^{9}$

\section{Characterizing Rangeland Vegetation}

The modified Daubenmire technique utilized by Clambey ${ }^{2}$ was used in 2007 on the same ecological site locations sampled in 1984. Twenty-five randomly placed quadrats were analyzed for each site in 1984 and 2007, and species within each quadrat were identified and aerial cover was estimated following the standard Daubenmire cover classes of $1-6 .{ }^{10}$ The relative cover for each species within a quadrat was calculated by utilizing the midpoint of each cover 


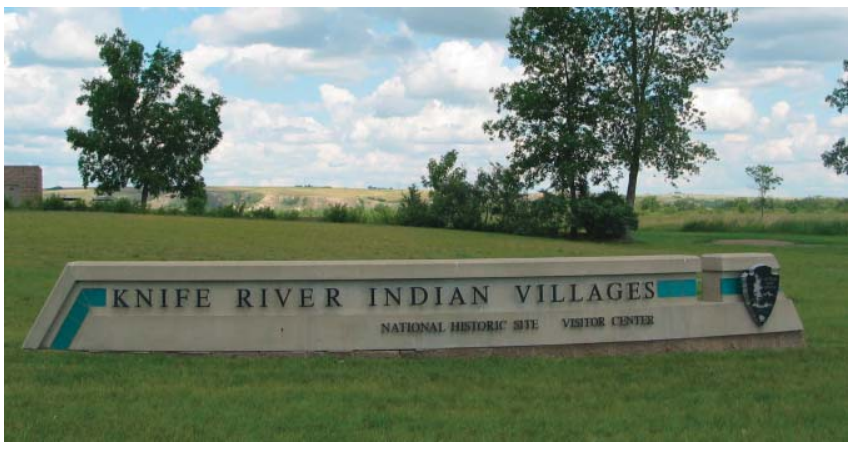

Figure 1. Knife River Indian Villages National Historic Site near Stanton, North Dakota.

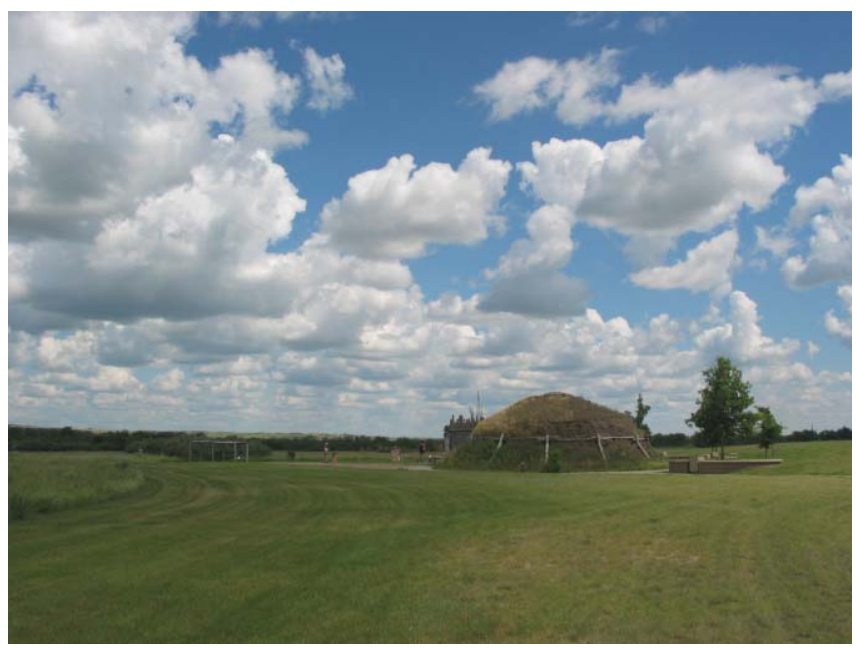

Figure 2. Historic Hidatsa earthlodge dwelling located on the Knife River Indian Villages National Historic Site.

class (e.g., $1=2.5,2=15$, etc.), and average relative cover was calculated by species for each site for 1984 and 2007 .

Species were then placed into the following groupings: brome, poa, NG (native grasses), NF (native forbs), IF (introduced forbs), and shrubs (all shrubs). Groupings between 1984 and 2007 were compared for sands, sandy, loamy, and loamy overflow ecological sites.

\section{Species Composition Changes}

The relative cover of vegetative groups changed notably over 23 years on each of the ecological sites (Figs. 3a-3d). The sands ecological site had significant increases in cover of brome and poa between 1984 and 2007, with reductions in native grasses and forbs (Fig. 3a). Brome and poa increased from $0 \%$ and $5 \%$ in 1984 to $40 \%$ and $23 \%$, respectively, in 2007. The sandy ecological site had poa increasing from $4 \%$ to $22 \%$ and native forbs decreasing from $34 \%$ to 14\% (Fig. 3b). Only the native forbs showed a decrease (31\% to $14 \%$ ) on the loamy overflow ecological site between 1984 and 2007 (Fig. 3c). The loamy ecological site reacted similarly to the sands ecological site with brome $(0 \%$ to $47 \%$ ) and poa (13\% to $34 \%$ ) increasing in cover, while native grasses (66\% to $4 \%)$ and forbs (24\% to $12 \%)$ were decreasing (Fig. 3d).
Under non-use management, smooth brome and Kentucky bluegrass impacted the species composition of individual ecological sites in central North Dakota (Fig. 3). The two invasive species are becoming the primary components of plant communities on the sites where non-use occurs and are replacing the native grasses and native forbs that were historically part of these communities (Fig. 4). Similarly, Murphy and Grant ${ }^{1}$ found smooth brome and Kentucky bluegrass dominance on idle native mixed grass prairie managed by the US Fish and Wildlife Service (USFWS) in the drift prairie ecoregion of central North Dakota. ${ }^{4}$ They surveyed non-use USFWS lands and adjacent privately owned prairie that were being managed for livestock production. Interestingly, the privately owned tracts had little to no smooth brome-dominated sites, which implied that smooth brome may be susceptible to grazing. Although Kentucky bluegrass was the dominant grass on the private tracts, the native grass and forb components were higher in certain areas of privately owned grazed tracts. Murphy and Grant ${ }^{1}$ also indicated that smooth brome might be able to outcompete Kentucky bluegrass in loam soils located in the glaciated region of central North Dakota. The significant increase in smooth brome cover in our survey on the loamy ecological sites would seem to support this statement. Considering that the majority of rangelands within the glaciated prairie region consist of loamy soils, these findings are especially notable.

Once invasion of native prairie tracts by smooth brome and Kentucky bluegrass has occurred, there might not be any recourse available for restoration. There is evidence that smooth brome may create favorable conditions for itself by enhancing the cycling of nitrogen in the soil. ${ }^{11}$ Smooth brome dominance increased under increased nitrogen compared to the native switchgrass. Also, smooth brome decomposes at a greater rate, which would naturally increase nitrogen levels in soils. Jordan et al. ${ }^{12}$ indicated that smooth brome could favor itself through soil modification, but may also condition the soil for invasion of other species such as leafy spurge (Euphorbia esula). These findings indicate that restoration of soil level processes may be essential prior to restoring native plant communities to these sites.

The competitive mechanisms of Kentucky bluegrass are less well-known; however, it does have the ability to form a dense root mat that restricts water to the upper portion of the soil. Sites where Kentucky bluegrass is the primary invader appear to maintain a higher representation of the native plant species composition, based on our results and those of Murphy and Grant. ${ }^{1}$ Invasion overall was much less, and native composition higher, on the Sandy ecological sites of KNRI. The soils of these sites are not well developed and are well drained as compared to the other ecological sites surveyed. Kentucky bluegrass is known to be susceptible to drought and heat stress, ${ }^{13}$ and the sandy ecological sites would exhibit the greatest drought- and heat-stressed conditions on KNRI. 

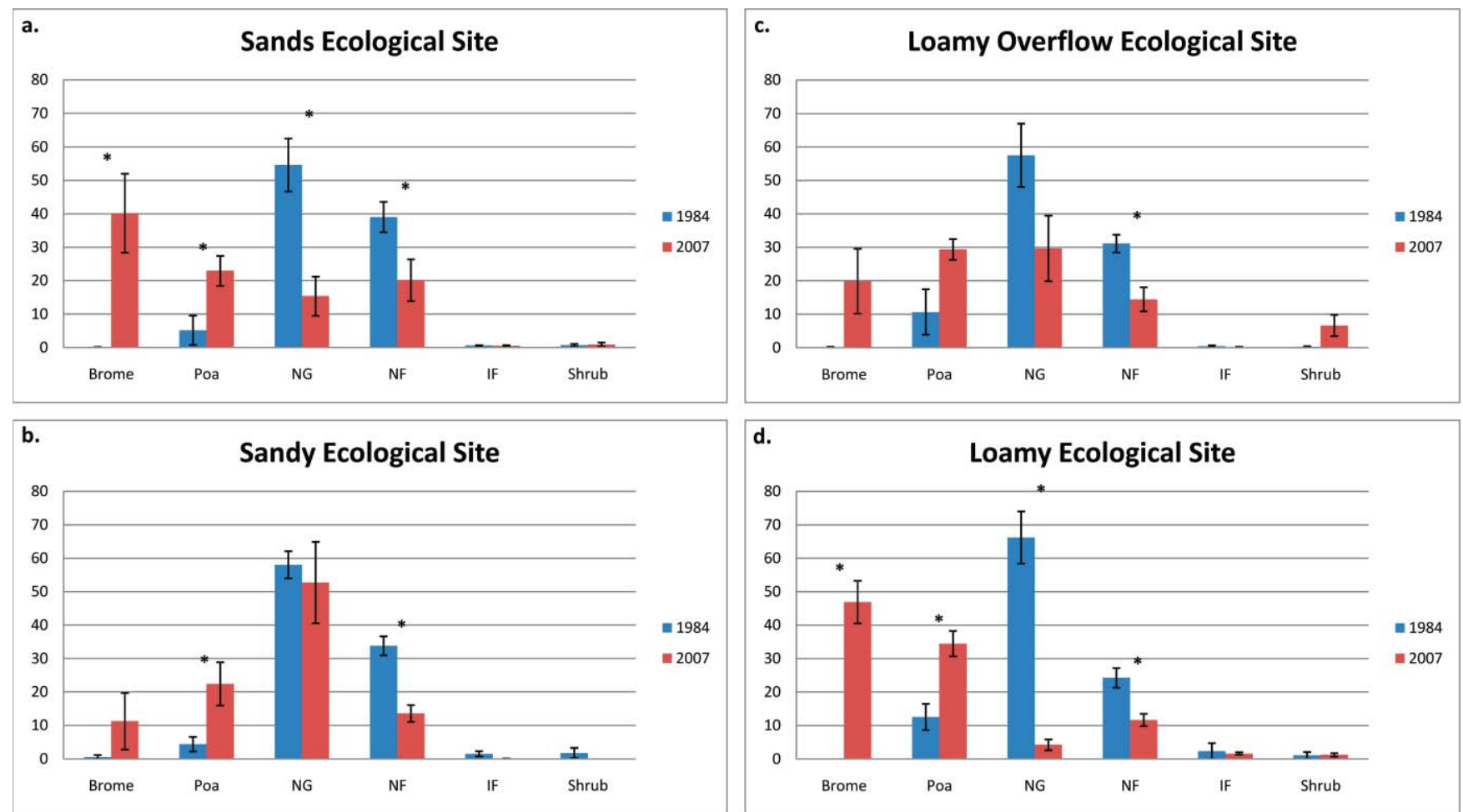

Figure 3. Relative plant cover (\%) of vegetative groupings on $\mathbf{a}$, sands; $\mathbf{b}$, sandy; c, loamy overflow; and $\mathbf{d}$, loamy ecological sites of the Knife River Indian Villages National Historic Site $\left(^{*}=\right.$ significant differences between 1984 and 2007 using a Student's $t$ test with significance level at $P=0.05)$.

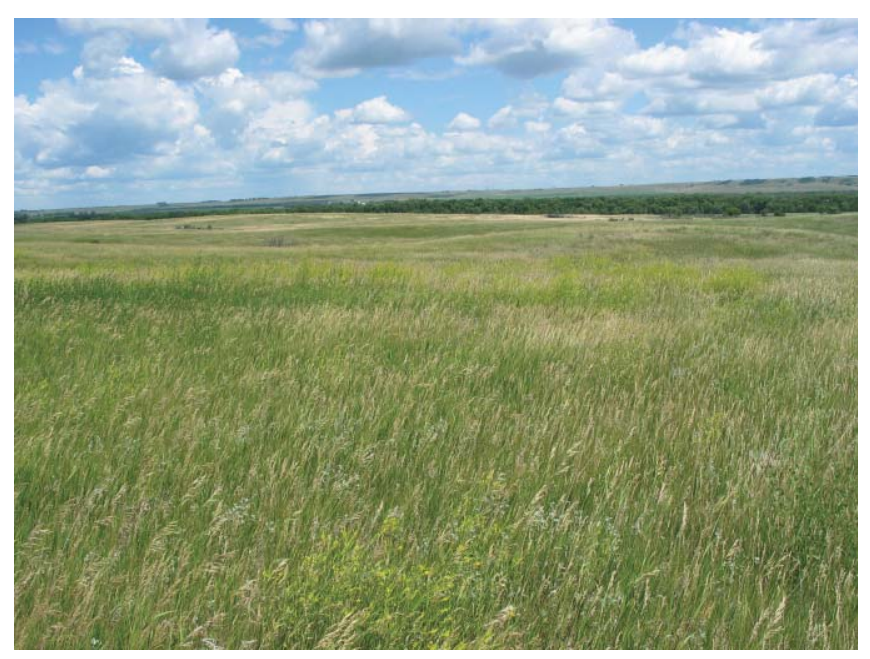

Figure 4. Loamy ecological site invaded by smooth brome on the Knife River Indian Villages National Historic Site.

\section{Future Management}

The plant communities of the Northern Great Plains have evolved with periodic fires and sometimes heavy utilization by native herbivores like bison, elk, and deer. Based on our findings and the findings of others, both grazing and fire should be reestablished on KNRI and other lands that have historically been managed with non-use. Grazing may impede smooth brome establishment, and, more importantly, prevent detrimental soil processes from developing.
Fire may establish conditions detrimental to Kentucky bluegrass, especially if timed with key developmental stages of Kentucky bluegrass ${ }^{14}$ or during stressful periods such as drought. ${ }^{15}$ Intuitively, the two historic processes applied together in natural patterns would favor those native species adapted to such conditions, as well as enhance the overall diversity of vegetation across landscapes. ${ }^{16}$ Finally, our findings, as well as those of others, indicate that long-term non-use on rangelands in central North Dakota is not a sensible option.

\section{References}

1. Murphy, R. K., and T. A. Grant. 2005. Land management history and floristics in mixed-grass prairie, North Dakota, USA. Natural Areas Journal 25:351-358.

2. Clambey, G. K. 1985. Vegetation baseline study for the Knife River Indian Villages National Historic Site. Fargo, ND, USA: US National Park Service and North Dakota State University Cooperative Agreement Report, Contract No. CX-12004AO44. $82 \mathrm{p}$.

3. DeKeyser, E. S., and K. Krabbenhoft. 2006. Prairie management plan for the Knife River Indian Villages National Historic Site. Stanton, ND, USA: US National Park Service and North Dakota State University Cooperative Agreement Report, Contract No. 6000A0100. 48 p.

4. Bryce, S. A., J. M. Omernik, D. E. Pater, M. Ulmer, J. Schaar, J. Freeouf, R. Johnson, P. Kuck, and S. H. Azevedo. 1998. Ecoregions of North Dakota and South Dakota (two-sided color poster with map, descriptive text, 
summary tables, and photographs; scale 1:1,500,000). Reston, VA, USA: US Geological Survey.

5. Barker, W. T., and W. C. Whitman. 1988. Vegetation of the Northern Great Plains. Rangelands 10:266-272.

6. USDa-Natural Resources Conservation Service. 2003. Field office technical guide, section 2, Major Land Resource Area 54, ecological site description: loamy. Site ID: R054XY031ND. Bismarck, ND, USA: NRCS State Office. $15 \mathrm{p}$.

7. USDa-Natural Resource Conservation Service. 2003. Field office technical guide, section 2, Major Land Resource Area 54, ecological site description: loamy overflow. Site ID: R054XY023ND. Bismarck, ND, USA: NRCS State Office. $15 \mathrm{p}$.

8. USDa-Natural Resource Conservation Service. 2003. Field office technical guide, section 2, Major Land Resource Area 54, ecological site description: sands. Site ID: R054XY025ND. Bismarck, ND, USA: NRCS State Office. $15 \mathrm{p}$.

9. USDA-Natural Resource Conservation Service. 2003. Field office technical guide, section 2, Major Land Resource Area 54, ecological site description: sandy. Site ID: R054XY026ND. Bismarck, ND, USA: NRCS State Office. $15 \mathrm{p}$.

10. Daubenmire, R. 1959. A canopy-coverage method of vegetational analysis. Northwest Science 33:43-64.

11. Vinton, M. A., And E. M. Goergen. 2006. Plant-soil feedbacks contribute to the persistence of Bromus inermis in tallgrass prairie. Ecosystems 9:967-976.

12. Jordan, N. R., D. L. Larson, and S. C. Huerd. 2008. Soil modification by invasive plants: effects on native and invasive species of mixed-grass prairies. Biological Invasions 10:177190.

13. Wang, Z., and B. Huang. 2004. Physiological recovery of Kentucky bluegrass from simultaneous drought and heat stress. Crop Science 44:1729-1736.

14. Grace, J. B., M. D. Smith, S. L. Grace, S. L. Collins, and T. J. Stohlgren. 2001. Interactions between fire and invasive plants in temperate grasslands of North America. In K. E. M. Galley and T. P. Wilson [EDs.]. Proceedings of the invasive species workshop: the role of fire in the control and spread of invasive species. Tallahassee, FL, USA: Tall Timbers Research Station. p. 40-65.

15. Engle, D. M., and P. M. Bultsma. 1984. Burning of northern mixed grass prairie during drought. Journal of Range Management 37:398-401.

16. Biondini, M. E., A. A. Steuter, and C. E. Grygiel. 1989. Seasonal fire effects on the diversity patterns, spatial distribution, and community structure of forbs in the northern mixed prairie, USA. Vegetatio 85:21-31.

Authors are Assistant Professor, School of Natural Resource Sciences, Range Program, North Dakota State University, Fargo, ND 58108, USA, edward.dekeyser@ndsu.edu (DeKeyser); Associate Professor, Department of Biological Sciences, North Dakota State University, Fargo, ND 58108, USA (Clambey); Rangeland Consultant, KDK Consulting, Fargo, ND 58104, USA (Krabbenhoft); and Nutrition Consultant, CHS Nutrition, Bismarck, ND 58501, USA (Ostendorf). 